\title{
Qat and its health effects
}

\author{
Y. A. M. El-Wajeh ${ }^{1}$ and M. H. Thornhill ${ }^{2}$
}

- Provides an up-to-date account of most recent qat related studies.

- Informs healthcare clinicians and more specifically dental clinicians about the possible oral health related changes induced by qat (plus systemic effects).

- Provides a clear opinion of the use of qat in the UK from a legal standpoint.

In Southern Arabia and Eastern Africa, qat chewing is a widely practised socio-cultural habit. It consists of placing the green-leaved plant into the mucobuccal fold and chewing it for several hours, with subsequent release of psychoactive agents. Qat chewing is often accompanied by smoking tobacco. The reported prevalence of qat chewing in Europe and North America is on the increase with global migration. Oral diseases reportedly associated with qat chewing include periodontitis, oral leukoplakia and oral cancer. However, precise data on the association of qat use with the development of oral cancer are sparse. The aim of this review is to 1) Educate health clinicians about qat usage and related oral/systemic health issues; and 2) Review the current literature regarding qat use and its association with oral disease but more specifically review its link with oral leukoplakia and oral squamous cell carcinoma (OSCC). To do this we searched the literature (PubMed, Science Direct and Scopus) to identify all relevant articles published over the last 20 years using a combination of terms 'qat', 'khat', 'kat', 'cathinone' and 'cathaedulis'.

\section{INTRODUCTION}

Head and neck cancer is a significant global health issue with over half a million new cases diagnosed per year and two-thirds of these cases occurring in developing countries. ${ }^{1}$ Annually an estimated 66,650 new oral cancer cases are diagnosed in the European Union. ${ }^{1}$ Every year in the UK more than 4,750 cases of oral cancer are diagnosed, with mortality rates of 1,700 in the UK each year. In the West, chronic tobacco smoking and alcohol consumption have been the most important of the known predisposing risk factors for the development of oral squamous cell carcinoma (OSCC), the two acting separately and synergistically. ${ }^{2}$ There are, however, a variety of habitual and culturally based

\footnotetext{
1*Sheffield Dental Vocational Training Scheme, Regional Postgraduate Dental Education Office, Don Valley House, Sheffield S4 7U0: ${ }^{2}$ Professor of Oral Medicine, Department of Oral \&t Maxillofacial Medicine \& Surgery, University of Sheffield School of Clinical Dentistry,

Claremont Crescent, Sheffield S10 2TA

*Correspondence to: Dr Yasin El-Wajeh

Email: elwajehy@hotmail.com
}

\section{Refereed Paper}

Accepted 22 September 2008

DOI: $10.1038 /$ sj.bdj.2008.1122

${ }^{\circledR}$ British Dental Journal 2009; 206: 17-21 activities that are less commonly seen in Europe and North America that are considered possible risk factors for the development of this type of cancer. ${ }^{3}$ One commonly cited risk factor found in ethnic communities in the UK is the habit of betel (areca) nut chewing, which is mainly chewed by Bangladeshis, whilst qat chewing (takhzeena), a similar cultural habit practised by communities stemming from Southern Arabia and Africa, is relatively unknown in European and North American medical and dental circles.

Qat (khat, miraa, cathine, cathinone) is a green-leaved plant that has been chewed for its stimulant effect for centuries (Fig. 1). The most active ingredients of qat are alkaloids such as cathinone and cathine. Cathinone is the main psychoactive constituent of qat, and has a similar action to amphetamine, inducing the release of dopamine, a neurotransmitter, from pre-synaptic storage. ${ }^{4,5}$ Purified cathinone is a Class C drug, and thus controlled by the Misuse of Drugs Act 1971, but when present in the form of qat, it has no legal implications in the UK, whereas certain European countries and the United States consider qat to be a controlled substance.
In 2005, the Advisory Council on the Misuse of Drugs (ACMD) was directed by the UK Government to set up a qat working group to re-address the matter of whether qat should be controlled by the Misuse of Drugs Act 1971. It concluded that the evidence of direct harm from qat chewing was not sufficient to recommend its control at present. However, the WHO Expert Committee on Drug Dependence also considered the problem and concluded that it was significant enough to look at the need for international control of qat. ${ }^{6}$ Both committees have recognised that qat use is becoming an increasingly more significant problem in the UK, with problematic use occurring in the UK within the Somali, Yemeni and Ethiopian communities where it is a major cultural phenomenon. ${ }^{7}$ These concerns are based on the fact that the global market of qat is on the increase with trade estimates of 7-10 tonnes per week entering the UK market alone. ${ }^{8}$ Its use is often increased following migration from these countries and is used by men and women, across a wide spectrum of age groups and social classes. These groups typically have high levels of male unemployment, poverty and low educational standards, and it is within 
these community groups where oral cancer incidence is most prevalent. No studies of oral cancer incidence in these ethnic populations in the UK has been undertaken to date.

The aim of this review is to:

1) Educate health clinicians about qat usage and related oral/systemic health issues

2) Review the current literature regarding qat use and its association with oral disease but more specifically to review its link with oral leukoplakia and oral squamous cell carcinoma (OSCC).

To do this we searched the literature (PubMed, Science Direct and Scopus) to identify all relevant articles published over the last 20 years using a combination of terms 'qat', 'khat', 'kat', 'cathinone' and 'cathaedulis'.

\section{ORO-DENTAL EFFECTS OF QAT}

Qat leaves are generally placed in the mouth in the lower distal mucobuccal fold and are chewed during social-cultural gatherings, creating a noticeable pouch, where the duration of chewing may usually last up to several hours at a time.

In a recent cross-sectional study it was found that qat chewing caused loss of periodontal attachment presenting either as increased pocket depth or gingival recession. ${ }^{9}$ From an oral health point of view, the chewing of qat is purported to increase the risk of periodontal disease, temporo-mandibular joint click and xerostomia. ${ }^{10}$

These findings are consistent with an earlier study which looked at the periodontal status of a population in the Yemen. It concluded that higher qat consumption correlates with an increased detrimental effect on the periodontium using the CPITN index of periodontal treatment need. ${ }^{11}$ Conversely, a microbiological based study, which looked at periodontal bacteria in sub- and supragingival bacteria, concluded that qat chewing is not detrimental to the periodontium, whilst a further study found no significant clinical difference in oral hygiene between qat chewers and non qat chewers. ${ }^{12,13}$

Whilst qat in itself is considered to be non-cariogenic, the high consumption of sugary drinks and concomitant use of sugar tablets to counteract the bitter taste of qat can lead to cervical caries (Fig. 2)

Qat tends not to discolour the oral mucosa as seen in betel nut chewing. Fluorosis of enamel is a common finding in the qat chewing population but the aetiology for this is predominantly the high fluoride concentration in drinking water in rural areas of qat growing countries. The fluoride content in qat has been shown to be low. ${ }^{14}$

There is a case report of qat induced plasma cell gingivitis, which disappeared after discontinuation of qat chewing. ${ }^{15}$ A further case report highlights the possible synergistic effect of qat in the development of OSCC of the floor of the mouth. ${ }^{16}$ These case reports highlight the importance of eliciting a good social history relevant to the patient's ethnic background on initial presentation of any intraoral changes.

One of the most important considerations from an oral health point of view is the relationship between qat chewing and the development of oral cancer (OSCC) and pre-malignant lesions. Qat chewing has been associated with an increased rate of oral cancer. ${ }^{17,18}$ Soufi et $a l .{ }^{17}$ speculated that there may be a link between qat chewing and oral malignancies. In some of the cases in the study, the malignant lesion developed at the site where the qat bolus was held. All subjects in this small retrospective study were non-smoking qat chewers.

A further retrospective survey undertaken in the Yemen looked at 649 cases of primary malignant tumours. Even though this study found that OSCC was the most prevalent of all cancers (18.3\%) occurring in this group, there was a significant occurrence of simultaneous tobacco consumption in these patients. ${ }^{19}$ This makes it difficult to deduce the precise role played by qat in the high prevalence of OSCC. Furthermore, the presence of dietary deficiencies, from a low fruit and vegetable intake, may predispose towards the development of oral cancers and this was not taken into consideration. ${ }^{20}$ However, this study correlates well with the findings of another study that found the practice of qat chewing was prevalent in patients with head and neck OSCC in Southern Arabia. ${ }^{18}$
One study found that half of qat chewers develop oral leukoplakias. ${ }^{21}$ This becomes a significant finding if we are led to believe that such lesions become cancerous in $2-12 \%$ of these patients as concluded in some studies. ${ }^{22-23}$ In contrast, Macigo et al. ${ }^{24}$ undertook a relative risk assessment, looking at the association between oral leukoplakia and use of tobacco, alcohol and qat in Kenya and concluded there was no association between oral leukoplakia and qat, whereas qat chewing, as mentioned above, has been reported to induce oral keratotic white lesions, but unlike tobacco use and chewing of betel nut, no direct association between the white oral mucosal lesions in qat users and development of oral malignancy was identified. ${ }^{24,25}$ Studies focusing on other socio-cultural practices showed that the prevalence of oral cancer and other precancerous lesions such as oral leukoplakia in the Yemen was related to shammah use (traditional smokeless tobacco), which is a widely practised habit in the population that also use qat. ${ }^{26}$

Ali et al. ${ }^{27}$ looked at histopathological changes in oral mucosa induced by qat chewing. Forty oral mucosal biopsies were taken from the buccal mucosa on the side preferred for qat chewing; 20 biopsies were taken from the opposite side and ten biopsies from the buccal mucosa of a non qat chewing control group. Even though histopathological changes were seen in the oral mucosa on the chewing side, these changes showed no evidence of malignancy. Another study also reported histopathological changes in the oral mucosa associated with qat chewing. These included acanthosis, abnormal rete ridges and hyperkeratosis but no evidence of carcinoma. ${ }^{28}$

The simultaneous use of tobacco consumption is a confounder in many of these studies. However, there are some studies where oral white lesions were found in qat chewers who were not smokers. ${ }^{29}$ Indeed the prevalence of such lesions and their severity correlated with duration and frequency of chewing, suggesting a possible dose response relation, as seen in other risk factors for oral white lesions, such as areca nut use. 


\section{Systemic effects of Qat}

Systemic effects of qat use involve the cardiovascular system, central nervous system, digestive and genitourinary systems. ${ }^{30-35}$ These include: hypertension, tachycardia, anorexia, insomnia, euphoria, loss of appetite, gastrointestinal disturbances and weak stream of micturition. There are studies that have looked at whether qat chewing is a risk factor for ischaemic heart disease and diabetes. Al-Motarreb et al. ${ }^{36}$ undertook a 100 patient based case-control study and found that qat chewing was an independent dose-related risk factor for the development of myocardial infarction. A further study concluded that chronic qat chewing does not increase serum glucose in healthy individuals but increases glucose and C-peptide levels during a qat session in diabetics. ${ }^{37}$ Both of these conditions have a high prevalence in the qat chewing population community in the UK.

From a pharmacological perspective, qat has been shown to affect the bioavailability of widely prescribed antibiotics, such as amoxicillin. ${ }^{38}$ The authors of the study recommended that the antibiotics in question should not be taken within two hours of qat chewing. A laboratory based study has also assessed the antimicrobial activity of qat extracts against a panel of oral microorganism and tested their ability to modify bacterial resistance to tetracycline and penicillin in vitro. The study concluded that qat has water-soluble constituents possessing selective antibacterial activity against the oral flora, as well as antibiotic resistance-modifying components that warrant further investigation to assess any implications for dental prescribing. ${ }^{39} \mathrm{~A}$ further in vitro study concluded that qat leaves contain water-soluble constituents that inhibit some cariogenic properties of $S$. mutans in vitro. ${ }^{40}$ These studies may send out a mixed message about the potential benefits and problems associated with qat use but equally highlight the need for further clinical and laboratory based research.

In the UK, the debate over the mental health and social implications of qat use has led to a demand from within the affected communities, for stricter legal control of this widely used plant. ${ }^{41}$

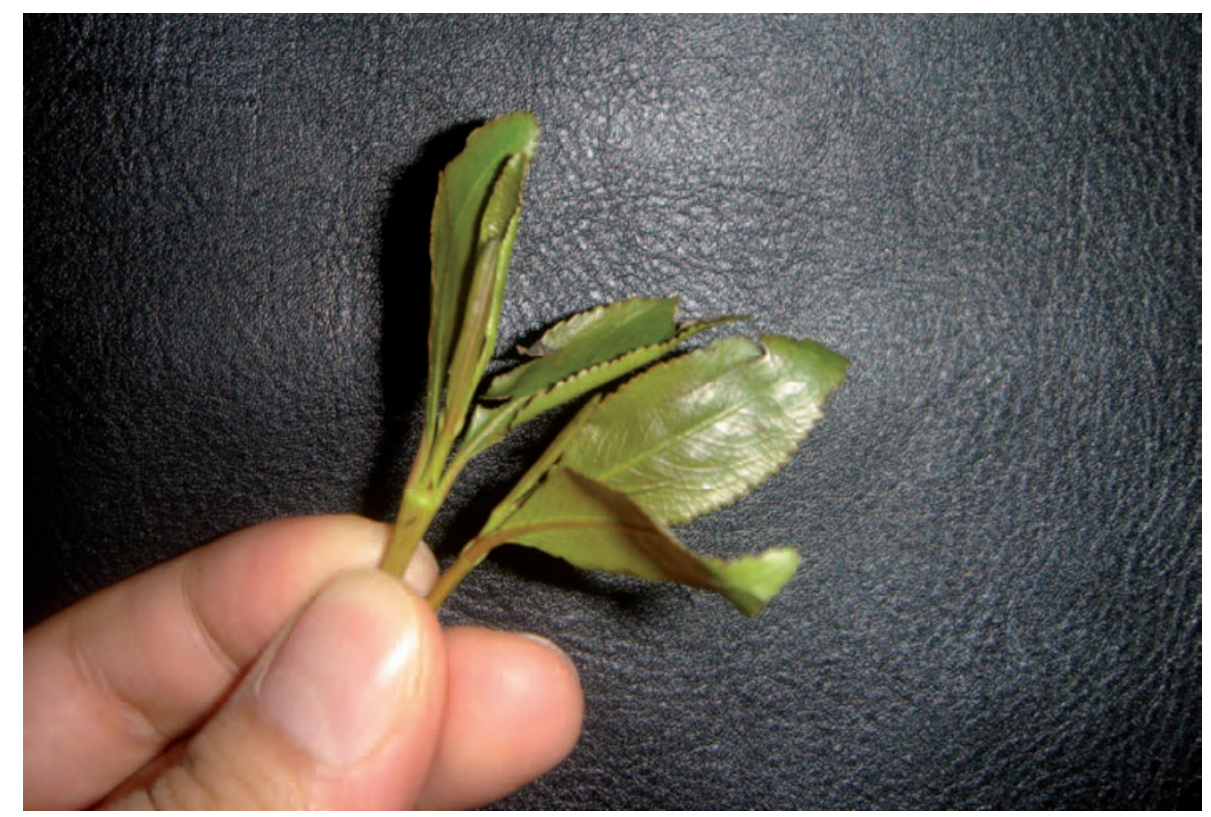

Fig. 1 Qat leaves

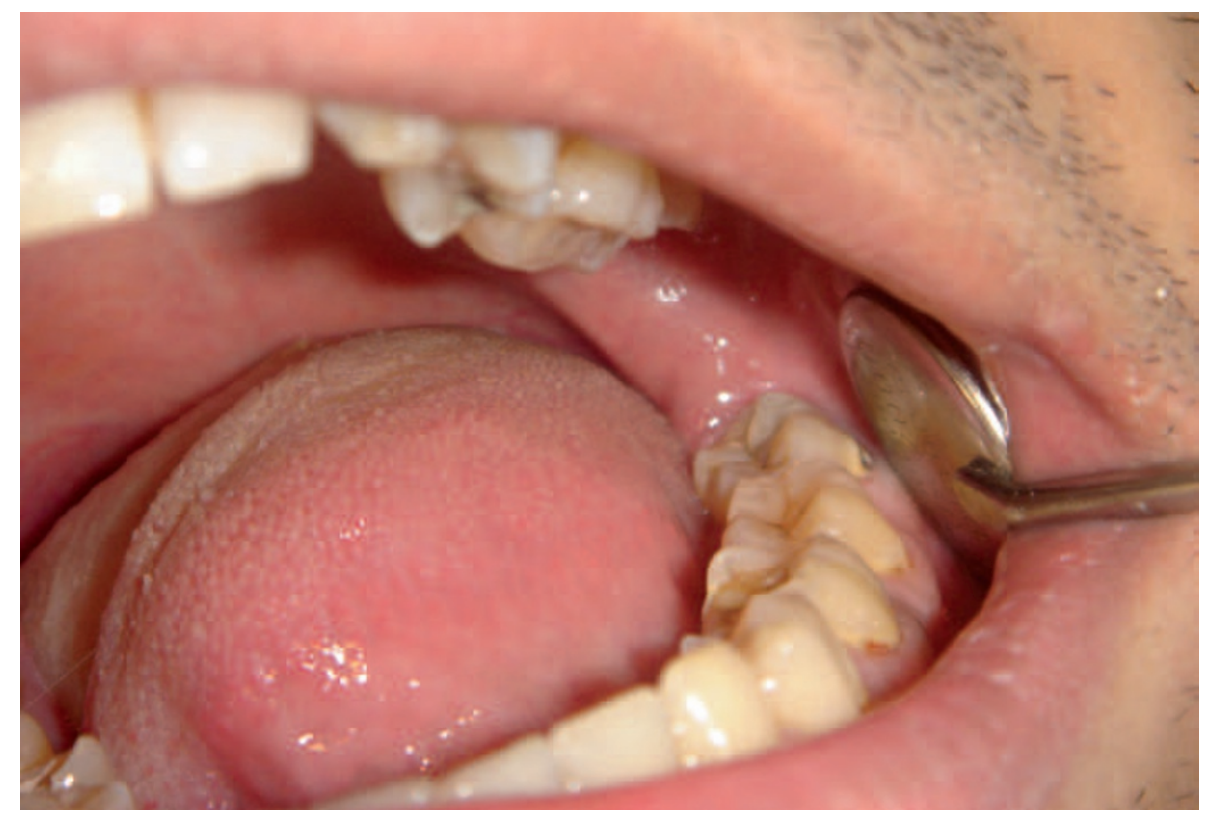

Fig. 2 Pattern of cervical caries related to qat chewing

Chemical pesticides are often used during the cultivation of qat and there is evidence that these may also cause adverse effects in chewers. ${ }^{42}$

\section{MOLECULAR-BASED STUDIES ON OAT}

On the molecular level, the effect of qat remains controversial but yet crucial to our understanding of whether qat is indeed a risk factor for oral cancer and its precursors.

Animal studies have shown qat to induce genetic mutations and teratogenic effects. ${ }^{43-45}$ A molecular based comparison study between the micronuclei formation of buccal cells in qat users to non qat-user controls and to a smoking, alcohol drinking, and qat chewing group, concluded that qat chewers had a significantly higher micronuclei frequency than non consumers ( $p=0.000047)$, indicative of aberrations at the cellular level. ${ }^{46}$ Qat was also shown to promote apoptotic cell death through mechanisms involving the activation of a family of cysteine proteases named caspases (caspase $-1,-3$ and -8 )..$^{47,48}$

A more recent paper investigated the effects of qat on human oral keratinocytes and human oral fibroblasts in respect to changes present at the cell cycle level. ${ }^{49}$ The results showed qat to have a strong inhibitory effect on the growth of these 
two cell types, with increased expression of tumour suppressor genes involving senescence related to differentiation. Whether these changes are mirrored in vivo is yet to be determined.

Further studies looking at whether qat induces genetic aberrations via activation of ras or induction of mutational hotspots in p53 tumour suppressor gene, as seen in the pathogenesis of betel-and tobacco-related oral cancers, would help in establishing whether qat should be considered carcinogenic. ${ }^{50,51}$

\section{CONCLUSION}

There is not enough evidence in the literature that qat chewing alone is carcinogenic or plays an independent direct role in the development of head and neck cancers. Unfortunately, the frequent combined use of qat and tobacco products makes it difficult to isolate the contribution each makes to the risk of developing oral cancer. Although the exact mechanism of any reported carcinogenesis is unknown, available information suggests that qat chewing should be considered one of the possible confounding risk factors for oral cancer specific to individuals who practise qat chewing along with tobacco use. What makes the claim that qat is directly a causative factor in OSCC difficult is the widespread simultaneous use of other known carcinogens such as polycyclic aromatic hydrocarbons and nitrosamines in the qat chewing population. ${ }^{52}$ An exploratory study by Kassim et al. ${ }^{53}$ concluded that qat chewing creates dependency and correlates with tobacco smoking and nicotine dependence.

The current situation in the UK is that there are no government health warning labels on bundles of qat, sales are unregulated and there's no restriction on its sale to minors. Any potential governmental intervention into the qat market in the UK, however, would need to take consideration of the fact that its use is culturally based and an integral part of the social interactions of certain communities.

Case-control studies would help to evaluate the risk for oral cancer and other associated oral mucosal diseases resulting from variations in qat chewing habits. However, due to the cost of conducting large population-based studies, it may be appropriate to conduct smaller-scale surveys and research studies first, to assess evidence for the validity of the possibility that qat is carcinogenic. Qat health education would carry a cost, and that cost has yet to be justified based on the current level of scientific data surrounding its use.

Currently there are no data on the effectiveness of qat cessation interventions and whether it is worth doing from an economic perspective. The National Institute for Health and Clinical Excellence (NICE) is stated to have a threshold of about £30,000 per Quality Adjusted Life Years (QALY). ${ }^{54}$ This means that any health intervention above this threshold is likely to be rejected and any intervention which has an incremental cost of less than or equal to £30,000 per extra QALY gained is likely to be accepted as cost-effective. Any qat cessation interventions would therefore need to be substantiated by good clinical data linking qat chewing to systemic and oral diseases. If there is a link that qat prevention and cessation interventions are effective then further studies would be beneficial to establish more accurately the extent to which qat chewers are at a higher risk of developing OSCC than non qat chewers.

In conclusion any appropriate public health programme would have to be based on scientifically sound data, which at present is not available.

The authors would like to thank Professor Peter G. Robinson, Professor of Dental Public Health at the School of Clinical Dentistry, Sheffield.

1. IARC. GLOBOCAN 2002. Cancer incidence, mortality and prevalence worldwide (2002 estimates). 2004.

2. Rodriguez T, Altieri A, Chatenoud L, Gallus S et al. Risk factors for oral and pharyngeal cancer in young adults. Oral Oncol 2004; 40: 207-213.

3. Goldenberg D, Lee J, Koch W et al. Habitual risk factors for head and neck cancer. Otolaryngol Head Neck Surg 2004; 131: 986-993.

4. Kalix P. Cathinone: a natural amphetamine. J Pharmacol Toxicol 192; 70: 77-86.

5. Patel N B. Mechanism of action of cathinone: the active ingredient of qat (Catha edulis). East Afr Med J 2000; 77: 329-332.

6. WHO Expert Committee on Drug Dependence. World Health Organ Tech Rep Ser 2006; 942: 1-21, 23-24 passim.

7. Nabuzoka D, Badhade F A. Use and perceptions of qat among young Somalis in a UK city. Addiction Res 2000, 8: 5-26.

8. Goudi A J. Importing qat, legal but dangerous (letter). Lancet 1987; ii: 1340-1341.

9. Ali A A. Qat habit in Yemeni society.A causative factor for oral periodontal diseases. Int J Environ Res Public Health 2007: 4: 243-247.
10. Al-Sharabi A. Oral and para-oral lesions caused by takhzeen (chewing) al-qat. Doctoral thesis. Al-Qattoum, Sudan: Univ Khartoum, 2002.

11. Mengel R, Eigenbrodt M, Schunemann T, Flores de-Jacoby L. Periodontal status of a subject sample of Yemen. J Clin Periodontal 1996; 23: 437-443.

12. Al-Hebshi N N, Skaug N. Effect of qat chewing on 14 selected periodontal bacteria in sub- and supragingival plaque of a young male population. Oral Microbiol Immunol 2005; 20: 141-146.

13. Jorgensen $E$, Kaimenyi J T. The status of periodontal health and oral hygiene of Miraa (Catha edulis) chewers. East Afr Med J 1990; 67: 585-590.

14. Hattab F N, Angmar-Mansson B. Fluoride content in qat (Catha edulis) chewing leaves. Arch Oral Biol 2000; 45: 253-255.

15. Marker P, Krogdahl A. Plasma cell gingivitis apparently related to the use of Khat: report of a case. Br Dent J 2002; 192: 311-313.

16. Fasanmade A, Kwok E, Newman L. Oral squamous cell carcinoma associated with khat chewing. Oral Surg Oral Med Oral Pathol Oral Radiol Endod 2007; 104: e53-e55.

17. Soufi H E, Kameswaran M, Malatani T. Qat and oral cancer. J Laryngol Otol 1991; 105: 643-645.

18. Nasr A, Qatri M. Head and neck squamous cell carcinoma in Hajjah, Yemen. Saudi Med J 2000; 21: 565-568.

19. Sawair FA, Al-Mutwakel A, Al-Eryani K, Al-Surhy A et al. High relative frequency of oral squamous cell carcinoma in Yemen: qat and tobacco chewing as its aetiological background. Int J Environ Health Res 2007: 17: 185-195.

20. Macfarlane GJ et al. Alcohol, tobacco, diet and the risk of oral cancer: a pooled analysis of three casecontrolled studies. Eur J Cancer B Oral Oncol 1995: 31B: 181-187.

21. Hill C M, Gibson A. The oral and dental effects of qat chewing. Oral Surg Oral Med Oral Pathol 1987; 63: 433-436.

22. Sankaranarayanan R. Oral cancer in India: an epidemiologic and clinical review. Oral Surg Oral Med Oral Pathol 1990; 69: 325-330.

23. Sankaranarayanan R, Duffy S W, Padmakumary $\mathrm{G}$ et al. Risk factors for cancer of the buccal and labial mucosa in Kerala, Southern India. J Epidemiol Community Health 1990; 44: 286-292.

24. Macigo F G, Mwaniki D L, Guthua S W. The association between oral leukoplakia and use of tobacco alcohol and qat based on relative risks association in Kenya. Eur J Oral Sci 1995; 103: 268-273.

25. Ali A A, Al-Sharab A K, Aguirre J M, Nahas R. A study of 342 oral keratotic white lesions induced by qat chewing among 2500 Yemeni. J Oral Pathol Med 2004; 33: 368-372.

26. Scheifele C, Nassar A, Reichart P A. Prevalence of oral cancer and potentially malignant lesions among shammah users in Yemen. Oral Oncol 2007 1: 42-50.

27. Ali A A, Al-Sharabi A K, Aguire J M. Histopathological changes in oral mucosa due to takhzeen al-qat: a study of 70 biopsies. J Oral Pathol Med 2006: 35: 81-85.

28. Ali A A. Histopathologic changes in oral mucosa of Yemenis addicted to water-pipe and cigarette smoking in addition to takhzeen al-qat. Oral Surg Oral Med Oral Pathol Oral Radiol Endod 2007: 103: e55-9

29. Ali A A, Al-Sharab A K, Aguirre J M, Nahas R. A study of 342 oral keratotic white lesions induced by qat chewing among 2500 Yemeni. J Oral Pathol Med 2004; 33: 368-372.

30. Hassan N A Gunaid A A, Murray-Lyon I M. Oat (Catha edulis): health aspects of qat chewing. East Mediterr Health J 2007; 13: 706-718

31. Hassan N A, Gunaid A A, El Khally F M, MurrayLyon I M. The subjective effects of chewing qat leaves in human volunteers. Ann Saudi Med 2002; 22: 34-37.

32. Nencini $P$, Ahmed A M, Elmi A. Subjective effects of qat chewing in humans. Drug Alcohol Depend 1986; 18: 97-105.

33. Al-Habori M. The potential adverse effects of habitual use of Catha edulis (qat). Expert Opin 
Drug Saf 2005; 4: 1145-1154.

34. Warfa N, Klein A, Bhui K et al. Qat use and mental illness: a critical review. Soc Sci Med July: 65: 309-318

35. Hassan N A, Gunaid A A, Abdo-Rabbo A A, AbdelKader $Z Y$ et al. The effect of qat chewing on blood pressure and heart rate in healthy volunteers. Trop Doct 2000; 30: 107-108.

36. Al-Motarreb A, Briancon S, Al-Jaber N, Al-Adhi $B$ et al. Khat chewing is a risk factor for acute myocardial infarction: a case-control study. Br J Clin Pharmacol 2005; 59: 574-581.

37. Saif-Ali R, Al-Qirbi A, Al-Geiry A, Al-Habori M. Effect of Catha edulis on plasma glucose and Cpeptide in both type 2 diabetics and non-diabetics. J Ethnopharmaco/2003; 86: 45-49.

38. Atef $O \mathrm{~A}$, Ali A A, Ali $\mathrm{H} \mathrm{M}$. Effect of qat chewing on the availability of ampicillin and amoxicillin. J Antimicrob Chemother 1997; 39: 523-525.

39. Al-Hebshi N, Al-Haroni M, Skaug N In vitro antimicrobial and resistance-modifying activities of aqueous crude qat extracts against oral microorganisms. Arch Oral Bio/ 2006; 51: 183-188.

40. Al-Hebshi N N, Nielsen O, Skaug N. In vitro effects of crude qat extracts on the growth, colonization, and glucosyltransferases of Streptococcus mutans. Acta Odontol Scand 2005; 63: 136-142.
41. Warfa N, Klein A, Bhui K, Leavey G et al. Qat use and mental illness: a critical review. Soc Sci Med 2007; 65: 309-318.

42. Date J, Tanida N, Hobara T. Qat chewing and pesticides: a study of adverse health effects in people of the mountainous areas of Yemen. Int J Environ Health Res 2004: 14: 405-414.

43. Tariq M, Parmar N S, Qureshi S et al. Clastogenic evaluation of cathinone and amphetamine in somatic cells of mice. Mutat Res 1987: 190: 153-157.

44. Li J H, Lin L F. Genetic toxicology of abused drugs: a brief review. Mutagenesis 1998; 13: 557-565.

45. Al-Zubairi $A$, Ismail $P$, Pei $C P$, Rahmat A. Genotoxic effect of Catha edulis (khat) crude extract after sub-chronic administration in rats. Environ Toxicol Pharmacol 2007; in press.

46. Kassie F, Darroudi F, Kundi M et al. Qat (Catha edulis) consumption causes genotoxic effects in humans. Int J Cancer 2001; 92: 329-332.

47. Dimba E A, Giertsen B T, Bredholt T et al. Qat (Catha edulis)-induced apoptosis is inhibited by antagonists of caspase- 1 and -8 in human leukaemia cells. Br J Cancer 2004; 91: 1726-1734.

48. Dimba E, Giertsen B T, Francis G W et al. Catha edulis (qat) induced cell death by apoptosis in leukaemia cell lines. Ann N Y Acad Sci 2003;
1010: 384-388

49. Lukandu O M, Costea D E, Dimba E A et al. Khat induces G-1 phase arrest and increased expression of stress-sensitive $p 53$ and $p 16$ proteins in normal human oral keratinocytes and fibroblasts. Eur J Oral Sci 2008: 116: 23-30.

50. Sawair FA, Al-Mutawakel A, Al-Eryani K, AlSurhy A et al. High relative frequency of oral squamous cell carcinoma in Yemen: qat and tobacco chewing as its aetiological background. Int J Environ Health Res 2007: 17: 185-195.

51. Ralhan R, Agarwal S, Nath N, Mathur M et al. Correlation between p53 gene mutations and circulating antibodies in betel- and tobacco-consuming North Indian population. Oral Onco/2001; 37: 243-250.

52. Warnakulasuriya K A, Tavassoli M, Johnson N W. Relationship of p53 overexpression to other cell cycle regulatory proteins in oral squamous cell carcinoma. J Oral Pathol Med 1998; 27: 376-381.

53. Kassim S, Croucher R. Qat chewing amongst UK resident male Yemeni adults: an exploratory study. Int Dent J 2006; 56: 97-101.

54. Devlin N. Parkin D. 'Does NICE have a costeffectiveness threshold and what other factors influence its decisions? A binary choice analysis.' Health Econ 2004 : 13: 437-452. 